\title{
Tax-financing of Budget Deficits in LDCs: Re-validation of Laffer Curve Theory
}

\author{
Samuel O.Okafor ${ }^{1}$, Olisaemeka D. Maduka ${ }^{1}$, Ann N. Ike ${ }^{2}$, Benedict I. Uzoechina ${ }^{3}$ \\ ${ }^{1}$ Department of Economics, Nnamdi Azikiwe University, Awka, Anambra State, Nigeria \\ ${ }^{2}$ Department of Banking and Finance, Federal Polytechnic, Oko, Anambra State, Nigeria \\ ${ }^{3}$ Department of Economics, Renaissance University, Ugbawka, Enugu, Enugu State, Nigeria \\ Correspondence: Samuel O. Okafor, Department of Economics, Nnamdi Azikiwe University, P.M.B. 5025, Awka, \\ Anambra State, Nigeria.
}

Received: February 3, 2017

Accepted: March 3, 2017

Available online: March 22, 2017

doi:10.11114/aef.v4i3.2297

URL: https://doi.org/10.11114/aef.v4i3.2297

\begin{abstract}
Urgent need for quick action to put Nigeria and other developing economies back to the path of economic recovery has almost imposed state of emergency on these economies. Most LDCs are faced with acute shortage of development funds due to recessions accompanying incessant crashes in international financial market. Raising existing tax rates to finance budget deficit in LDCs often generates public debate on pros and cons of such policy option. Study considered Nigeria as typical case of LDCs. Study focused on establishing the effectiveness of tax-financing of budget deficit under Laffer curve theory. Study spanned across 1970-2015. Data were analyzed using ADF, CUSUM, heteroskedasticity, multiple regression, Johansen cointegration and ECM. Results indicate that: (1) Custom and exercise duties, petroleum profit tax and value-added tax contributed significantly to the reduction in budget deficit while company income tax had nonsignificant impact(2)Total government revenue constituted major chunk of planned income for budget deficit financing(3) Deficit financing of capital health expenditure yielded high returns while that of recurrent education expenditure and capital education expenditure was accompanied by low returns (4)Growth and employment generation accelerated deficit financing while private investment decelerated it (5) There were long and short-run relationships among budget deficit, taxes, human capital investment and macroeconomic indicators with significant rate of adjustment of short-run disequilibrium. Study concluded that tax-financing of budget deficit was effective under Laffer curve effect. It was recommended, among others, that LDCs should enlarge their tax bases through inclusion, to finance budget deficit.
\end{abstract}

Keywords: deficit financing, tax-financing, fiscal deficit, Laffer curve analysis, econometric validation

\section{Introduction}

Budget deficits have become a common feature in Nigeria's budgetary process. Ariyo and Raheem (1991) had stated that budget deficit has become a recurring feature of Nigeria's fiscal policy. Deficit budget policy is an instrument of fiscal policy used to increase the rate of economic growth of the country (Gaber, 2010). When there is a budget deficit, government finds ways of financing the deficit through borrowing from commercial banks or from non banking public and through the issue of short-term bonds and monetary instrument (Paiko, 2012). Nigeria's budget estimates showing estimates of federal government revenues (GRV), federal government expenditure (GEX), and federal government budget deficits (GBD) for the period, 2006-2015 have been presented in Table1. 
Table 1. Nigeria’s Budget Estimates 2006-2015 (N Billion)

\begin{tabular}{llll}
\hline Year & GRV & GEX & GBD \\
\hline 2006 & 5965.102 & 6066.500 & -101.397 \\
2007 & 5715.600 & 5832.837 & -117.237 \\
2008 & 7866.590 & 7913.969 & -47.378 \\
2009 & 4844.592 & 5654.601 & -810.008 \\
2010 & 7303.672 & 8409.113 & -110.544 \\
2011 & 3410.100 & 3541.900 & -131.800 \\
2012 & 3572.520 & 3845.100 & -272.500 \\
2013 & 3905.380 & 4046.800 & -141.420 \\
2014 & 3672.030 & 3983.000 & -310.950 \\
2015 & 2859.020 & 3469.160 & -610.140 \\
\hline
\end{tabular}

Source : Central Bank of Nigeria's Statistical Bulletin

Table1 shows that estimated GEX exceeded GRV thereby yielding GBD between 2006 and 2015. While GEX and GRV had downward trends, GBD had an upward trend in the same period.

Nigeria has continued to rely on domestic and external borrowing to finance its budget deficits. Borrowing is the commonest means of deficit financing (Gaber, 2010). Often, financing budget deficit through borrowing leads to crowding out of private investment, inflation and future debt burden (Paiko, 2012). The Nigerian experience of deficit financing via external borrowing has been one of frustration of conscientious effort of the government to put back the Nigerian economy to the path of economic recovery. Deficit financing via external borrowing has resulted to high-extension debt stock and debt burden which had dampened investment through debt overhang effect, and crowding out effect. This is the situation in Nigeria where excessive foreign indebtedness has remained a major impediment to economic growth and stability (Audu, 2004).

Rising external debt in Nigeria has raised public hue and cry. Federal government (FG) response has been expressed in the search for alternative source of deficit financing. The choice of tax as a means of deficit financing was informed by public awareness that "deficit finance only temporarily delays taxation (if the time path of government spending is held constant), and that current tax rates are lower and future tax rates are higher than they otherwise would have been" (Trostel, 1995). It is in this context that the recommendation made by the Managing Director of IMF, Christine Lagarde to the FG to increase value-added tax (VAT) rate which currently stands at 5 per cent (one of the lowest in the world) has received the endorsement of the Buhari administration. FG proposal to raise VAT rate from 5 per cent to 10 per cent and FG's recent raising of other tax rates have evoked mixed reactions of the general public. While it is incontestable that raising tax rates would yield huge revenues to the government, it is arguable that higher tax rates in future would reduce income which in turn would reduce the future net wage that is the return on current human capital (Trostel, 1995). Along this line, Laffer (2004) had posited that raising tax rates discourages production in the taxed activities.

Therefore, the study was undertaken with the broad objective of determining the extent to which deficit financing through taxation would be effective. Specific objectives include the following:

1. To determine the extent to which tax components contribute to budget deficit financing.

2. To determine the extent to which government revenue contributes to budget deficit financing.

3. To determine the extent to which human capital components contribute to budget deficit financing.

4. To determine the extent to which macroeconomic indicators contribute to budget deficit financing.

5. To determine the nature of relationships among budget deficit, tax components, government revenue, human capital components and macroeconomic indicators.

Answers were sought to the following research questions: (1) To what extent do various tax components contribute to budget deficit financing? (2) To what extent does government revenue contribute to budget deficit financing? (3) To what extent do human capital components contribute to budget deficit financing? (4) To what extent do macroeconomic indicators contribute to budget deficit financing?

Following null hypothesis was verified: There is no significant relationship among budget deficit, tax, government revenue, human capital and macroeconomic indicators.

Certainly, the answers to these research questions and the facts from the verified hypothesis would serve as concrete evidences for validating Laffer curve theory for application in Nigeria and other developing economies. Unless the status of tax components as instrument of deficit financing is precisely determined, the conundrum posed by FG's proposal to raise VAT rate and FG's recent raising of other tax rates would remain unresolved. 
It is in this context that the results of this study were considered useful to fiscal authorities in developing economies who would take into cognizance the Laffer curve effect while considering an option for deficit financing through taxation.

\section{Review of Related Literature}

\subsection{Theoretical Literature}

\section{Keynesian Theory of Deficit Financing}

Keynes was a great protagonist of deficit financing. He found deficit financing a veritable tool of economic prosperity and fiscal discipline. Keynes had suggested the use of deficit financing to fight cyclical depression in capitalist countries and eliminate massive unemployment. According to Keynes, employment is a function of propensity to consume. He had recommended deficit financing for funding public works projects in order to enhance the purchasing power of the people and to increase effective demand. Keynes laid emphasis on the use of public borrowing to augment tax revenue and savings for financing development projects and infrastructures. However, in India deficit financing does not include borrowing from people and commercial banks. Rather they include borrowing from the Reserve Bank of India, withdrawal of part accumulated cash balances and issuing of fresh currency by the government. It is referred to as market borrowing (Tasneem, 2016). Keynes referred to this as multiplier effect.

Keynes theory of deficit financing has limited applicability in the Nigerian situation. This is because the use of public borrowings for financing budget deficit has not been effective for eliminating unemployment, recovering the economy from recession and sustaining steady economic growth (Paiko, 2012). However, the Nigerian experience of the use of public borrowing for budget deficit financing has created the need for an alternative source of deficit financing. It is from this that the present study derives its relevance from Keynes multiplier effect theory.

\section{Laffer Curve Theory of Tax Financing}

This theory was put forth by Arthur B. Laffer in 1974.The theory posits that changes in tax rates have arithmetic and economic effects on tax revenue.The arithmetic effect is that when tax rates are lowered there would be a corresponding decrease in tax revenues. In the same vein, when tax rates are raised, there would be a corresponding increase in tax revenues. According to Laffer (2004) the economic effect of lowering tax rates is that it impacts positively on work, output and employment thereby creating incentive for increasing state activities. The reverse is the case when tax rates are raised- raising tax rate discourages production in the taxed activities. There is always a conflict between arithmetic and economic effects leading to a negligible impact of changes in tax rates on tax revenue. In his own contribution Mitchell (2010) had recommended that policy makers should set tax rate at the growth-maximizing level rather than revenue-maximizing level. The Laffer curve itself does not show whether a tax cut will lower or raise tax revenues. Revenue response to changes in tax rate will depend on the tax system in place, time period under consideration, accessibility to underground activities, the current tax rate, the prevalence of legal and accounting-driven tax loopholes and the productivities of the productive factors.

Laffer curve theory might possibly have policy implications for Highly Indebted Poor Countries (HIPC) and developing economies such as Nigeria in their use of tax revenues for financing development projects and infrastructures. In this way, Laffer curve theory has raised serious issues bordering on the effectiveness of FG's raising of tax rates for budget deficit financing in Nigeria. It is in this perspective that Laffer curve analysis has been considered to be relevant to the present study.

Keynesian theory of deficit financing and Laffer curve theory of tax-financing have proved very useful for an in-depth understanding of the importance of deficit financing in fighting cyclical depression in capitalist countries. Howbeit, an informed choice of Laffer curve theory as a theoretical base of this study has been made over Keynesian theory due to the overriding emphasis of the former on the effect of changes in tax rate on tax revenue. While Keynesian theory emphasized public borrowing to augment tax revenue and savings for financing fiscal deficit, Laffer curve theory had expressed the impact of tax changes in terms of arithmetic and economic effects with conflict between the two culminating into the emergence of a more powerful effect which stresses that raising tax has opposite effect by penalizing participation in the taxed activities. The wider implication of Laffer curve theory was extended in a "parameterized neoclassical (exogenous) growth model with human capital under the assumption of perfect foresight" ( Trostel, 1995). Therefore, it follows that deficit finance delays taxation temporarily and that current tax rates are lower and future tax rates are higher than they otherwise would have been. If taxes are based on income, an increase in the tax rate would lead to a reduction in future net wage rate which is the return on current human capital investment. Also, a decrease in the current tax rate leads to increase in the current net wage rate which is the principal value of the current human capital investment. This effect on human capital investment determines to a large extent how budget deficits affect other important variables such as consumption, work, investment in physical capitals, output, net wage rate and employment. These variables have been included in the model used for this study. In fact, there is no more appropriate 
theory than Laffer curve theory for exploring the economic consequences of raising tax rate to finance budget deficit.

\subsection{Empirical Literature Review}

Several studies have been carried out in this area. Only recent studies have been reviewed in this section in order to determine the extent to which deficit financing still engages the attention of scholars and researchers in Nigeria and overseas.

Thapa (2005), embarked on a study titled "Deficit financing: Implications and management." Study covered the period, 1987-2004. Study was essentially a qualitative research adopting theoretical method of data analysis. Study revealed that excessive deficits and heavy borrowing to finance that deficit drain out the resources of the developing countries. It was concluded that financing budget deficit through borrowing usually leads developing countries to comfortable liquidity profile which is implicit in effective debt management. The policy implication of the finding is that developing countries should augment their total revenues through borrowing to finance their budget deficit and enhance growth. The relevance of this study for the present article is its result which has been used to compare with findings of the present study.

Upender (2008) carried out a study to determine the degree of buoyancy of tax system in India. Study employed OLS involving multiple regression technique, Augmented -Dickey Fuller (ADF) and Phillips Perron (PP) tests. Findings indicate that : (1) Gross tax was moderately elastic (2) Average propensity to tax was increasing with increase in GDP during the pre-tax period (3) There was a downward shift in the degree of tax buoyancy during the post-tax reform period (4) Average propensity to tax was decreasing during the post- tax reform period. Policy implication of findings of this study is the need for developing economies to test the validity or otherwise of Laffer curve theory in order to determine its applicability in their economies. The weakness of the study is the ambiguity in its results. Despite this, the study was considered relevant to the present study which has adopted its evidences to support the analytical framework used in this study.

Gaber (2010) investigated the economic implications of deficit finance for growth. He adopted qualitative analysis of the major growth effects of deficit financing including multiplier effect, crowding out effect and twin deficit effect. Study revealed that the implication of multiplier effect for growth is to increase aggregate demand and national income while the implication of crowding out effect for growth is to crowd out private sector from the capital market under increased demand for loan-able funds. This study has its strength in its detailed analysis of various growth effects of fiscal deficit. It has been considered relevant to the present study which has adopted its conclusions for discussing the results of the study.

Jadhav and Neelankavil (2011) embarked on a study to identify economic factors affecting national debt which would serve as early warning indicators to indebtedness.Panel data were used for the study. Study employed multiple regression and VAR techniques for the analysis of data. Study revealed that there was no single economic factor to serve as early warning indicator of rising national indebtedness and that there was no single corrective measure to avert rising indebtedness. Policy implication of findings to governments is the need to carry out a detailed analysis of the economic situation in their countries before resorting to external borrowing. A drawback of the study is the misapplication of regression technique for identifying factors. Only exploratory factor analysis (EFA) and confirmatory factor analysis (CFA) are appropriate tools for identifying factors. However, the study was found relevant to the present study as it sought to derive strength from the weakness of this study.

Ogunmuyiwa (2011) evaluated the status of fiscal deficit as a determinant of external debt in Nigeria. Study spanned across 1970-2007. Study employed econometric tools of unit root, Granger causality, OLS and Chow break point test for the analysis of data. Study revealed that a structural shift existed in the pattern of deficit and debt in Nigeria but no causal relationship existed between the variables. Policy implication of this finding is that FG should commit external borrowing to funding development projects and infrastructure rather than financing recurrent expenditures. A limitation of this study is the failure to determine the extent to which fiscal deficit contributed to external borrowing in Nigeria. Nonetheless, the results of the study served as an eye-opener for a correct interpretation of the results of data analysis in the present study.

Paiko (2012) studied the implication of deficit financing for achieving higher investment in the private sector of the Nigerian economy. The study spanned across 1990-2007. Study employed OLS technique. Study revealed that there was an inverse relationship between deficit financing and investment in the private sector of the Nigerian economy. It was recommended that FG should adopt a fiscal policy which would be conducive for high rate of productive investment in the private sector. A serious limitation of this study is the application of regression technique for the analysis of data from extremely small sample $(\mathrm{n}=18)$. Nonetheless, the study was considered relevant to the present study which has found its results suitable for making comparison.

Omojimite and Iboma (2012) investigated the relationship between fiscal deficit and productivity of the Nigeria's tax 
system. Study spanned across 1970-2010. Study employed OLS involving multiple regression for the analysis of data. Results indicate that: (1) There was a relatively weak productive tax system in Nigeria (2) Petroleum profit tax was perfectly elastic during the oil boom and the SAP. These findings have policy implication for the FG to broaden the tax base and improve on administration of tax collection. The weakness of the study could be traced to shift of research focus from responsiveness of fiscal deficit to tax productivity rather than the relationship between the two. However, the study was considered relevant to the present study as it has created a deep insight into the productivity of Nigeria's tax system.

Ndedzu, Macheka, Ithiel and Zivengwa (2013) carried out a study to determine the revenue productivity of Zimbabwe's tax system. The study spanned across 1975-2008. Data were analyzed using OLS technique involving multiple regression. Results indicate that: (1) Tax system and other taxes in Zimbabwe, except custom duties, were not buoyant (2) Discretionary measures were effective for generating additional tax revenues. Study recommended improvement on tax administration, reduction in tax evasion and reduction in the number of tax exemptions. The findings have policy implication for governments in developing countries to reform their tax system in order to maximize tax revenues without frequent discretionary changes in tax structure.This study is relevant to the present study as it has yielded results to serve as a prior expectation.

Oriakhi and Osemwengie (2013) studied the impact of tax incentives on revenue productivity of tax system in Nigeria. The study covered the period, 1981-2009. Data were analyzed using OLS involving multiple regression. Study revealed that: (1) Total revenue productivity of tax system in Nigeria was unsatisfactory (2) There were lagging sources of FG revenues in Nigeria (3) Tax revenues in Nigeria were not buoyant due to poor tax effort. Study recommended a reduction in fiscal deficit of FG budget in order to stem the tide of rising public expenditures. The findings have policy implication for government to recourse to tax rather than borrowing for financing their budget deficit. A drawback of this study is the use of multiple regression technique for the analysis of data from small sample $(n=29)$. However, the study was considered relevant as it has provided evidences to direct efforts in the present study.

Keho (2013) carried out a study on tax structure and economic growth in Cote d'Ivoire. Study covered the period, 1961-2006. Study employed OLS revolving around multiple regression technique for the analysis of data. Study revealed that increases in tax burden and the share of direct tax to total tax revenue were strongly associated with decrease in economic growth. Policy implication of finding is the need for government to adopt a growth-maximising tax structure in the financing of its budget deficit.This study was found very useful for validating the results of the present study.

Onwe (2014) studied the implication of deficit financing for economic growth in Nigeria. The study spanned across 1970-2013. Data were analyzed using multiple regression technique. Findings indicate that: (1) External borrowing, non-banking public source and exchange rate had positive impact on economic growth (2) Ways and means, bank borrowing and interest rate had negative impact on economic growth. Policy implication of findings to government is the need to use deficit financing as a veritable tool for maintaining economic stability. The results of this study find applicability in the present article by ways of contributing variables which have be included in the present study.

Samuel and Tyokoso (2014) studied the impact of taxation on revenue generation in selected states of Nigeria. Study spanned across 2002-2011. Sample comprised of 300 members of federal and state Inland Revenue Services and 100 tax payers. Data were analyzed using descriptive statistics, inferential statistics and multiple regression technique. Results indicate that: (1) Taxation contributed significantly to revenue generation (2) Taxation contributed significantly to GDP (3) Tax evasion and tax avoidance had significant impact on revenue generation. Policy implication of finding is the need for government to adopt effective administrative measures to curb tax evasion and avoidance in order to enhance tax revenues. Major limitation of this study is its recommendations which were not based on findings of the study. Howbeit, the study created an insight into the problems of tax administration in Nigeria.

Ojo (2014) carried out a study aimed at determining the impact of deficit financing on growth in Nigeria. Study covered the period, 1970-2010. Study employed econometric tool of Vector Auto Regression for the analysis of data. Study revealed that deficit financing had negative impact on economic growth in Nigeria. The finding has policy implication to the government for ensuring greater budgetary discipline and adopting financial structural transformation in order to reduce wastage in public spending. A drawback of the study is the recommendations made outside the scope of the study which has amounted to extrapolation. Notwithstanding, this study served as a nucleus of the entire proceeding in the present study.

Edame and Okoi (2015) investigated the relationship between fiscal deficit and economic growth in Nigeria via Chow's perspective. Study employed ADF, cointegration test and Chow endogenous break test for the analysis of data. Results indicate that: (1) There was a significant difference between civilian and military regimes based on fiscal deficits (2) Growth effect of fiscal deficit was significantly greater during the military regime than during the civilian regime (3) Growth effect of interest rate was not significant during military and civilian regime while growth effect of gross fixed 
capital formation was significant during both regimes. Study recommended the reduction in the current lending rate so as to ensure increased access to investment funds by domestic entrepreneurs. Policy implication of findings to government is the need to harness the relationship between fiscal deficit and growth toward achieving sustainable growth. A major weakness of this study is the recommendations which were not based on findings of the study. Howbeit, the study was still useful in yielding evidences which served as a prior expectation for the present study.

Nwaeke and Korgbeelo (2016) studied the impact of deficit financing on economic growth in Nigeria. Study covered the period, 1981-2013. Data were analyzed using OLS involving multiple regression. Results indicate that :(1) Budget deficit financing via external borrowing had negative, though nonsignificant impact on economic growth (2) Budget deficit financing via domestic banking system and non bank public sources had positive significant impact on economic growth (3) Deficit financing did not contribute significantly to inflation in Nigeria (4) Budget deficit financing via domestic sources contributed significantly to unemployment. Policy implication of findings to FG is the need to consider the far-reaching implications of budget deficit financing via public borrowing before embarking on it. The weakness of this study is in the ambiguity of its findings. Nevertheless, it has yielded variables which have been included in the model adopted for the present study.

\subsection{Summary of Review}

Theoretical review revealed that both Keynesian and Laffer curve theories were firm in their postulation that deficit financing is a veritable tool for augmenting government revenues. Perhaps, another glaring outcome of the review is that the line of demarcation between the two theories was not so much of the difference in their contents as it is of the relative importance each theory attaches to taxation as an instrument of deficit financing. While Keynesian theory emphasized the use of public borrowing to augment tax revenues and savings, Laffer curve theory had stressed that raising tax rates has opposite effect by penalizing participation in the taxed activities. It is the need for a detailed analysis of this opposite effects of raising taxes on taxed activities which is critical to this study. Certainly, it is the desire to accomplish this which has placed a high value on the Laffer curve theory for use in the present study.

On empirical side, review has revealed that deficit financing has remained a contentious issue in Nigeria and other developing countries. Moreover, literature is replete with studies which have yielded abundant evidences on the outcome of financing budget deficit through public borrowing. Not many studies had delved into determining the relative merits of public borrowing, taxation and monetization for financing budget deficit in developing countries. Even when such studies exist, there is still no conscientious effort toward revalidating Laffer curve theory in developing economies. It is this lacuna in empirical literature which was sought to be filled in the present study.

\section{Methods}

\subsection{Design of the Study}

It was designed essentially as a correlational study. Correlational design was considered appropriate as the study sought to carry out, from Laffer curve theoretical perspective, a detailed analysis of the interrelationships among different tax components, government revenue, human capital components, macroeconomic indicators and budget deficit. Only by gaining an insight into the nature of relationships among these variables can Laffer curve theory be validated as an instrument for formulating a dynamic policy of deficit financing through taxation for Nigeria and other developing economies.

\subsection{Nature of Data}

This study considered Nigeria as a typical example of developing economies; therefore, it was essentially a case study of Nigeria. Data were sourced from the Central Bank of Nigeria, National Bureau of Statistics and World Development Indicators. Data were collected for the period, 1970-2015. The choice of the variables and their inclusion in the analysis were strictly in conformity with the requirement of two relevant theories more particularly the Laffer curve theory which has constituted the theoretical base of the study.

To determine the nature of data, the unit root test was applied for ascertaining whether or not the time series data were stationary. The results of unit root test have been presented in Table2. 
Table 2. Unit Root Test for Stationarity of Time Series Data

\begin{tabular}{llll}
\hline Variables & $\begin{array}{l}\text { ADF test } \\
\text { statistics }\end{array}$ & $\begin{array}{l}\text { Prob. } \\
\mathrm{p} \leq 0.05\end{array}$ & $\begin{array}{l}\text { Order of } \\
\text { integration }\end{array}$ \\
\hline Budget deficit financing (BDF) & 3.984 & 0.006 & $1(1)$ \\
Total government revenue (TGR) & -7.077 & 0.000 & $1(1)$ \\
Company income tax (CIT) & -3.792 & 0.006 & $1(1)$ \\
Custom and exercise duties (CED) & -7.044 & 0.000 & $1(1)$ \\
Petroleum profit tax (PPT) & -5.001 & 0.000 & $1(1)$ \\
Value-added tax (VAT) & -3.848 & 0.009 & $1(1)$ \\
Recurrent education expenditure (REE) & -6.379 & 0.000 & $1(1)$ \\
Recurrent health expenditure (RHE) & -7.438 & 0.000 & $1(1)$ \\
Capital education expenditure (CEE) & -8.869 & 0.000 & $1(1)$ \\
Capital health expenditure (CHE) & -8.180 & 0.000 & $1(1)$ \\
Private investment (PIV) & -6.368 & 0.000 & $1(1)$ \\
Private consumption expenditure (PIV) & -6.498 & 0.000 & $1(1)$ \\
Gross domestic product (GDP) & 2.958 & 0.040 & $1(1)$ \\
Employment (EMP) & -6.494 & 0.000 & $1(1)$ \\
\hline
\end{tabular}

As can be seen in Table 2, BDF, TGR, CIT, CED, PPT, VAT, REE, RHE, CEE, CHE, PIV, PCE, GDP and EMP had ADF values with $\mathrm{p} \leq 0.05$, thereby warranting the rejection of null hypothesis of the presence of unit root in all the variables. Thus, all were stationary at order one or first difference.

\subsection{Model Specification}

As previously stated, the broad objective of this study was to determine the effectiveness of tax-financing of budget deficit. In other words, the study sought to determine the extent to which raising tax rates would be grossly and suitably appropriate for financing budget deficit. Laffer curve theory and parameterized neoclassical growth model provided the theoretical base for this study. While Laffer curve theory had established a theoretical link among tax rates, tax revenue, output and employment, parameterized neoclassical growth model established theoretical link among budget deficit, consumption, investment in physical capital, output and employment. It is in this context that the present study assumed a functional relationship among deficit financing, tax rates, tax revenue, output, employment, consumption and investment in physical capital. Thus, the model for this study has been derived from Paiko's 2012 model expressed in the form:

$$
\mathrm{Yt}=\mathrm{F}\left(\mathrm{S}_{1}, \mathrm{~S}_{2}, \mathrm{~S}_{3}, \mathrm{~S}_{4}\right)(1)
$$

Where $Y t=P_{1}$ (private investment); $S_{1}=G_{M}$ (government expenditure public sector borrowing from the commercial banking system); $\mathrm{S}_{2}=\mathrm{G}_{\mathrm{B}}$ (budget deficit); $\mathrm{S}_{3}=\mathrm{X}_{\mathrm{D}}$ (external debt stock); $\mathrm{S}_{4}=\mathrm{R}_{\mathrm{T}}$ (interest rate). The model was modified and adopted in the form:

$$
\mathrm{BDF}=\mathrm{F} \text { (TGR, CIT, CED, PPT, VAT, REE, RHE, CEE, CHE, PIV, PCE, GDP, EMP(2) }
$$

$\mathrm{BDF}=\beta_{0}+\beta_{1} \mathrm{TGR}+\beta_{2} \mathrm{CIT}+\beta_{3} \mathrm{CED}+\beta_{4} \mathrm{PPT}+\beta_{5} \mathrm{VAT}+\beta_{6} \mathrm{REE}+\beta_{7} \mathrm{RHE}+\beta_{8} \mathrm{CEE}+\beta_{9} \mathrm{CHE}+\beta_{10} \mathrm{PIV}+\beta_{11} \mathrm{PCE}+\beta_{12} \mathrm{GDP}+\beta_{13} \mathrm{EMP}+\mu \mathrm{t}(3)$ Model 3 has been presented in logarithmic (Ln) form:

$\mathrm{LnBDF}=\beta_{0}+\beta_{1} \mathrm{LnTGR}+\beta_{2} \mathrm{LnCIT}+\beta_{3} \mathrm{LnCED}+\beta_{4} \mathrm{LnPPT}+\beta_{5} \mathrm{LnVAT}+\beta_{6} \mathrm{LnREE}+\beta_{7} \mathrm{LnRHE}+\beta_{8} \mathrm{LnCEE}+\beta_{9} \mathrm{LnCHE}+\beta_{10} \mathrm{LnPIV}+\beta_{11} \mathrm{LnPCE}$ $+\beta_{12} \operatorname{LnGDP}+\beta_{13} \operatorname{LnEMP}+\mu \mathrm{t}(4)$

Where $\beta_{0}=$ constant term; $\beta_{1, \ldots, \beta_{13}}=$ coefficients of the predictor variables respectively; $\mu \mathrm{t}=$ error term.

\subsection{Test for Model Stability}

Accuracy of prediction with any model depends partly on correct specification of the model. Therefore, it has become necessary to test the stability of the model specified in this section, i.e., to rule out the possibility of specification error which might occur due to the inclusion of irrelevant variables and exclusion of relevant variables. To test the stability of the model, the researchers verified the following null hypothesis $\left(\mathrm{H}_{0}\right.$ : Model is not well specified). The graph of Recursive Estimate CUSUM Test has been presented in Figure1. 


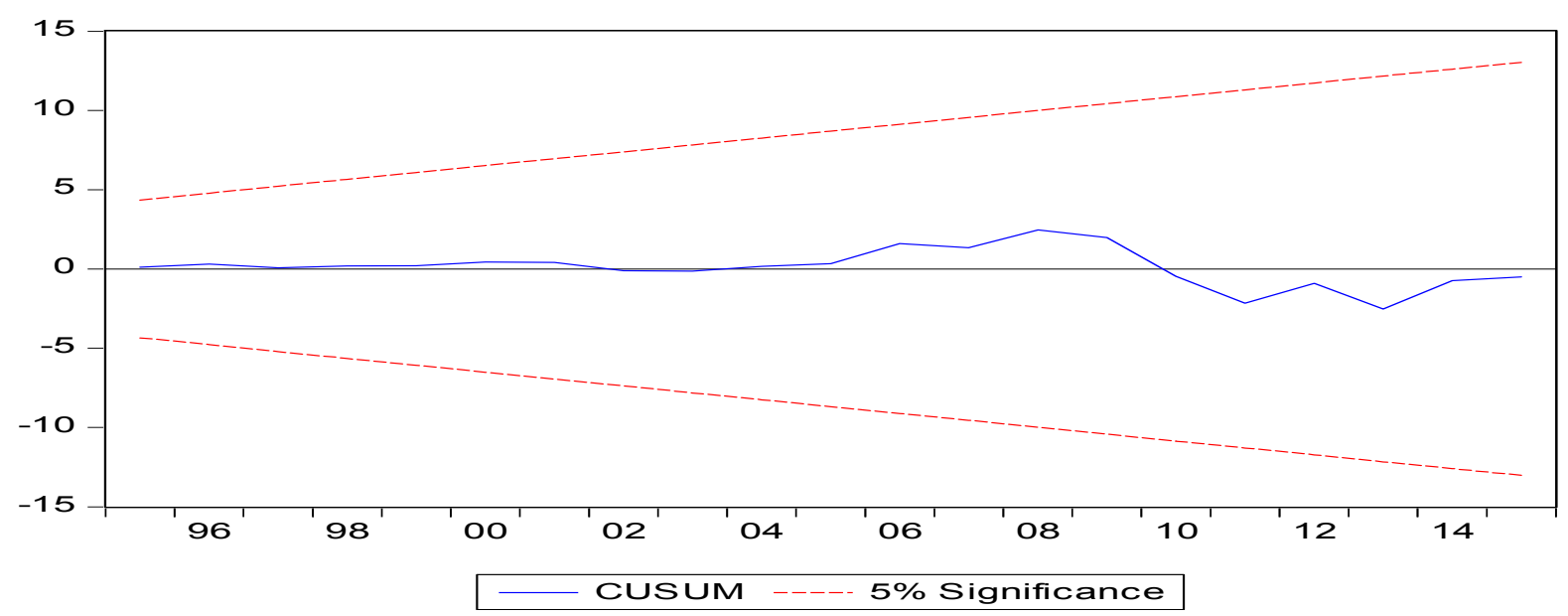

Figure1. CUSUM Graph.

As can be seen in Figure1, the model which is represented by the line in the middle is within the upper and lower bounds. This has warranted the rejection of the null hypothesis. Thus, the model was well specified, thereby serving as an indication of the stability of the model, i.e., there was no specification error in the model.

\subsection{Method of Data Analysis}

Once the stationarity of time series data and the stability of the model were established, the researchers employed ordinary least squares (OLS), heteroskedasticity test (white), Johansen cointegration, and error correction model (ECM) for the analysis of data.

The use of OLS yielded Beta ( $\beta$ ) coefficients, multiple correlation coefficient $\left(\mathrm{R}^{2}\right)$, F statistic, and Durbin-Watson (D.W.) which served the purposes described as follows: $\beta$ coefficient was applied to determine the contribution of predictor variables to $\mathrm{BDF}$ (criterion); $\mathrm{R}^{2}$ served to determine the percentage of total variance in criterion variable explained by all the predictor variables; F value was used to verify the significance of the overall regression; D.W. was used for verifying the existence of serial autocorrelation in the model. White test was applied for confirming the homoskedasticity of the model. Johansen cointegration test was used to ascertain whether or not long-run equilibrium relationship existed between BDF and predictor variables. ECM was applied to verify the short-run relationship between BDF and predictor variables.

\section{Results}

The results of data analysis in Tables 3, 4 and 5, were interpreted to provide answers to the research questions and to verify the null hypothesis formulated in Section 1. The results in Table 3 have been interpreted to provide answers to Research Questions 1, 2, 3 and 4, while results in Table 4 were used for verifying the null hypothesis. Also, the results in Table 5 were used to check the speed of adjustment between the long and short-run equilibrium relationships under appropriate sub-headings. 


\subsection{Main Characteristics of Fiscal Operations on Budget Deficits in Nigeria}

Table 3. Results of Regression of BDF (Criterion) on TGR, CIT, CED, PPT, VAT, REE, RHE,CEE, CHE, PIV, PCE, GDP and EMP (Predictors)

\begin{tabular}{|c|c|c|c|c|c|c|c|c|c|c|}
\hline \multirow[b]{2}{*}{ S.No } & \multirow[t]{2}{*}{ Criterion } & \multicolumn{4}{|c|}{ LNBDF } & \multirow{2}{*}{\multicolumn{2}{|c|}{$\begin{array}{l}\mathrm{R}^{2} \text { Adjusted } \\
\mathrm{R}^{2}\end{array}$}} & \multirow[b]{2}{*}{ F-statistic } & \multirow[b]{2}{*}{ D.W. } & \multirow[b]{2}{*}{ White Test } \\
\hline & & $\beta$ coefficient & $\begin{array}{l}\text { Contribution to BDF } \\
\text { per unit increase }\end{array}$ & Prob. & Decision & & & & & \\
\hline 0 & C & 1.916 & 1.916 & 0.933 & Nonsignificant & & & & & \\
\hline 1 & LNTGR & -4.236 & -4.236 & 0.005 & Significant & & & & & \\
\hline 2 & LNCIT & 1.880 & 1.880 & 0.683 & Nonsignificant & & & & & \\
\hline 3 & LNCED & -6.523 & -6.523 & 0.005 & Significant & & & & & \\
\hline 4 & LNPPT & -4.196 & -4.196 & 0.035 & Significant & & & & & \\
\hline 5 & LNVAT & -2.082 & -2.082 & 0.007 & Significant & & & & & \\
\hline 6 & LNREE & 3.978 & 3.978 & 0.035 & Significant & & & & & \\
\hline 7 & LNRHE & 7.120 & 7.120 & 0.358 & Nonsignificant & & & & & \\
\hline 8 & LNCEE & 1.565 & 1.565 & 0.009 & Significant & & & & & \\
\hline 9 & LNCHE & -6.558 & -6.558 & 0.007 & Significant & & & & & \\
\hline 10 & LNPIV & 2.340 & 2.340 & 0.036 & Significant & & & & & \\
\hline 11 & LNPCE & 1.314 & 1.314 & 0.570 & Nonsignificant & & & & & \\
\hline 12 & LNGDP & -6.630 & -6.630 & 0.008 & Significant & & & & & \\
\hline \multirow[t]{2}{*}{13} & LNEMP & -9.383 & -9.383 & 0.010 & Significant & & & & & \\
\hline & & & & & & 0.934 & 0.826 & $\begin{array}{c}866.651 \\
(p \leq 0.000)\end{array}$ & 2.390 & $\begin{array}{l}\mathrm{F}(\mathrm{p} \geq 0.578) \\
\chi^{2}(\mathrm{p} \geq 0.516)\end{array}$ \\
\hline
\end{tabular}

Table 3 shows that beta coefficient for the constant=1.916 implies that in absence of tax-financing of budget deficit and any other macroeconomic policy, BDF increased by 1.916 units. $\mathrm{R}^{2}=0.934$ implies that the predictor variables in the model explained 93.4 per cent of the total variance in BDF. Thus, the model was a good fit. Adjusted $\mathrm{R}^{2}=0.826$ implies that even if more variables were included in the model, the predictor variables would still explain 82.6 per cent of the total variance in BDF thereby confirming the goodness of fit of the model. F statistic $=866.651(\mathrm{p} \leq 0.000)$ implies that the overall regression result was significant and suitable for the purposes of prediction. D.W., approximately 2 implies the absence of serial autocorrelation in the model, thereby justifying the use of beta coefficients for predicting BDF accurately. $F=0.882(p \geq 0.578), \chi^{2}=12.137(p \geq 0.516)$ implies that the assumption of homoskedasticity was not violated by the model.

\section{Research Question 1}

To what extent do various tax components contribute to deficit financing?

As can be seen in Table 3, beta coefficients for CED (-6.523, $\mathrm{p} \leq 0.005)$, PPT $(-4.196, \mathrm{p} \leq 0.035)$ and VAT $(-2.082$, $\mathrm{p} \leq 0.007)$ were significant. These results indicate that CED, PPT and VAT impacted negatively on BDF. In other words, CED, PPT and VAT were effective tax components for financing budget deficit in Nigeria.

\section{Research Question 2}

To what extent does revenue generation meet the demand for budget deficit financing?

Table 3 shows that TGR had beta coefficient $=-4.236(\mathrm{p} \leq 0.005)$. Now, since $\mathrm{p} \leq 0.005$ is less than $\mathrm{p} \leq 0.05$, beta coefficient of -4.236 was considered to be significant at 0.05 confidence interval. This result suggests that TGR contributed significantly to the reduction of budget deficit in Nigeria. In other words, TGR was sizeable enough to constitute major chunk of planned income for deficit financing.

\section{Research Question 3}

To what extent do human capital components contribute to budget deficit financing?

Also, Table 3 shows that REE had beta coefficient $=3.978(\mathrm{p} \leq 0.035)$, while CEE and CHE had beta coefficients $=$ $1.565(p \leq 0.009)$ and $-6.558(p \leq 0.007)$ respectively. Now, since $p \leq 0.035, p \leq 0.009$ and $p \leq 0.007$ are less than $p \leq 0.05$, they were considered to be significant at 0.05 confidence interval. These results suggest that while CHE impacted negatively on BDF, REE and CEE contributed positively to BDF. In other words, deficit financing of CHE constituted a high rate of productive investment while deficit financing of REE and CEE had low returns.

Research Question 4

To what extent do macroeconomic indicators contribute to budget deficit financing?

From Table 3, out of the four macroeconomic indicators included in the model only PIV $(\beta=2.340, p \leq 0.036)$, GDP $(\beta=$ $-6.630, p \leq 0.008)$ and EMP $(\beta=-9.383, p \leq 0.010)$ contributed significantly to the BDF. The negative signs for beta 
coefficients of GDP and EMP indicate that GDP and EMP led to the reduction of BDF. The positive sign for PIV suggests that PIV induced an increase in BDF. Thus, economic growth and employment generation in Nigeria acted as incentive to deficit financing while PIV served as disincentive to deficit financing.

Hypothesis

There is no significant relationship among budget deficit, tax, government revenue, human capital and macroeconomic indicators.

Table 4. Results of Johansen's Test of Cointegration between BDF (Criterion) and Predictor Variables

\begin{tabular}{lllllll}
\hline $\mathrm{H}_{0}$ & Trace Statistic & $\begin{array}{c}0.05 \\
\text { Critical Value }\end{array}$ & Prob. & $\begin{array}{l}\text { Max-Eigen } \\
\text { Statistic }\end{array}$ & $\begin{array}{c}0.05 \\
\text { Critical Value }\end{array}$ & Prob. \\
\hline $\mathrm{r} \leq 0$ & $390.620^{*}$ & 125.615 & 0.000 & $370.620^{*}$ & 185.615 & 0.000 \\
$\mathrm{r} \leq 1$ & $123.725^{*}$ & 95.754 & 0.000 & $113.725^{*}$ & 97.754 & 0.002 \\
$\mathrm{r} \leq 2$ & $163.990^{*}$ & 95.754 & 0.000 & $153.990^{*}$ & 85.754 & 0.001 \\
$\mathrm{r} \leq 3$ & $104.216^{*}$ & 69.819 & 0.000 & $124.216^{*}$ & 69.819 & 0.000 \\
$\mathrm{r} \leq 4$ & $57.560^{*}$ & 47.856 & 0.005 & $55.560^{*}$ & 37.856 & 0.004 \\
$\mathrm{r} \leq 5$ & 5.086 & .15 .495 & 0.800 & 3.086 & 12.495 & 0.599 \\
$\mathrm{r} \leq 6$ & 0.201 & 3.841 & 0.654 & 0.601 & 3.541 & 0.454 \\
$\mathrm{r} \leq 7$ & 58.351 & 69.819 & 0.290 & 58.351 & 65.819 & 0.280 \\
$\mathrm{r} \leq 8$ & 27.791 & 47.856 & 0.823 & 17.791 & 43.856 & 0.853 \\
$\mathrm{r} \leq 9$ & 12.466 & 29.797 & 0.914 & 18.466 & 27.797 & 0.934 \\
$\mathrm{r} \leq 10$ & 5.184 & 15.495 & 0.789 & 4.184 & 15.495 & 0.799 \\
$\mathrm{r} \leq 11$ & 0.538 & 3.841 & 0.463 & 0.538 & 3.741 & 0.493 \\
$\mathrm{r} \leq 12$ & 0.031 & 3.841 & 0.861 & 0.631 & 3.641 & 0.891 \\
$\mathrm{r} \leq 13$ & 0.399 & 3.841 & 0.528 & 0.899 & 3.841 & 0.578 \\
\hline
\end{tabular}

Table 4 shows that five trace statistics and maximum eigen values were significant. This has warranted the rejection of the null hypothesis. Thus, there was a significant long-run equilibrium relationship between BDF and the predictor variables

It has become necessary, with the existence of long-run relationship among variables in the model to apply error correction model in order to distinguish between the short-run dynamics and long-run relationship. The results of error correction model analysis have been presented in Table 5.

Table 5. Results of Error Correction Model Analysis

\begin{tabular}{|l|l|l|l|l|}
\hline Variable & Coefficient & Std.Error & t-Statistic & Prob. \\
\hline C & 1.916 & 22.116 & 0.087 & 0.933 \\
D(LNTGR) & -0.058 & 0.072 & -3.811 & 0.023 \\
D(LNCIT) & 0.126 & 0.351 & 0.358 & 0.723 \\
D(LNCED) & -0.022 & 0.094 & -4.239 & 0.005 \\
D(LNPP) & -0.181 & 0.065 & -2.797 & 0.015 \\
D(LNVAT) & -0.015 & 0.041 & -2.374 & 0.011 \\
D(LNREE) & 1.106 & 0.213 & 5.203 & 0.000 \\
D(LNRHE) & 0.074 & 0.204 & 0.365 & 0.718 \\
D(LNCEE) & 0.484 & 0.185 & 2.609 & 0.015 \\
D(LNCHE) & -0.006 & 0.288 & -2.122 & 0.042 \\
D(LNPIV) & 0.706 & 0.050 & 14.139 & 0.000 \\
D(LNPCE) & 0.760 & 0.865 & 0.878 & 0.387 \\
D(LNGDP) & -1.729 & 0.695 & -2.486 & 0.019 \\
D(LNEMP) & -0.191 & 0.064 & -2.998 & 0.006 \\
ECM(-1) & -0.243 & 0.073 & -3.317 & 0.002 \\
\hline
\end{tabular}

Table 5 shows that ECM coefficient $=-0.243(\mathrm{p} \leq 0.002)$. The negative sign of ECM coefficient shows that it was rightly signed. This indicates that the short-run disequilibrium converged in the long-run. It was also considered to be significant since the $p \leq 0.002$ is less than $p \leq 0.05$. The ECM coefficient is the speed of adjustment of budget deficit to shocks and dynamics of tax components and macroeconomic indicators. Thus, the 24 per cent speed of adjustment was significant thereby implying that 24 per cent shocks was corrected over a period of one year. These results indicate that deficit financing through taxation was an effective fiscal policy. 


\subsection{Summary of Major Findings}

The major findings which have crystallized from this study include the following:

1. Custom and exercise duties, petroleum profit tax and value-added tax contributed significantly to the reduction in budget deficit while company income tax had nonsignificant impact.

2. Total government revenue was sizeable enough to constitute major chunk of planned income for budget deficit financing.

3. Deficit financing of capital health expenditure yielded high returns while that of recurrent education expenditure and capital education expenditure was accompanied by low returns to investment.

4. Economic growth and employment generation acted as incentive to tax-financing of budget deficit while private investment served as disincentive to it.

5. There were long and short-run relationships among budget deficit, taxes, human capital investment and macroeconomic indicators with significant rate of adjustment of short-run disequilibrium.

\section{Discussion of Findings and Conclusions.}

\subsection{Discussion of Findings}

The major findings of this study have been discussed in this section in order to give it a pride of place in economic literature.

The finding that custom and exercise duties, petroleum profit tax and value-added tax contributed significantly to the reduction in budget deficit while company income tax had nonsignificant impact has not stirred up a whirlwind. What could be better desired for a country which is wholly import dependent, heavily reliant on oil and most populous in the continent? For a wholly import dependent country, custom and exercise duties would constitute a vibrant tax component. It is also a truism that for wholly oil-reliant country and a large market economy, petroleum profit tax and value-added tax would be viable sources. That company income tax failed to contribute to reduction in budget deficit has come much in expectation. This is because lack of basic infrastructures such as electricity, roads, railways, water, etc. has forced several multinational corporations to relocate to neighbouring West African countries. Many manufacturing firms and industries which could not relocate due to paucity of funds have shut down. Thus, it is illogical to expect a high yield from this tax component. Perhaps, it is the relationship among budget deficit, custom and exercise duties, petroleum profit tax and value-added tax, implicit in the negative signs of their beta coefficients which appear to be knotty issues to address. However, with a glean insight into the critical path of transmission of their impact, it could be established that the negative signs imply that the yields from these tax components reduced drastically the size of budget deficit. This is also tantamount to eroding the viability of the taxes, and in consequence, a sharp reduction in the capacity of the tax payers. This finding contradicts the finding reported by Omojimite and Iboma (2012) that there was relatively weak productive tax system in Nigeria.

Another finding of the study is that total government revenue was sizeable enough to constitute major chunk of planned income for budget deficit financing. Surprising? The answer is emphatically 'No'. Nigeria, as a major exporter of crude oil derives over 70 per cent of its total revenue from the sale of crude oil representing about 60 per cent of its GDP. Therefore, federally collected revenue from both oil and nonoil sectors were so grossly adequate to 'gap-finance' the planned income-planned expenditure schedule through investment in capital projects. So, this is not so much of the problem of non-correspondence between planned income and planned expenditure in the budget schedule as it is of issue of subtle relationship considered earlier in this section, but this time between budget deficit and total government revenue. The inverse relationships among budget deficit, total government revenue, custom and exercise duties, petroleum profit tax and value-added tax implicit in the negative signs on their beta coefficients in this scheme have revealed that widening budget deficit led to sharp reduction in total government revenue through the erosion of tax buoyancy. This finding is consistent with finding of Ndedzu et al.(2013) that tax system and taxes in Zimbabwe except custom duties were not buoyant. This brings it immediately to the track followed by Laffer (2004) who argued that raising taxes could lead to disincentives to invest. In this way, laffer curve theory has found applicability in the Nigerian situation.

Moreover, there is the finding that deficit financing of capital health expenditure yielded high returns while that of recurrent education expenditure and capital education expenditure was accompanied by low returns to investment. It is only a rational expectation that tax-financing of capital projects on health will generate high returns. It has already been established in this section that tax-financing of budget deficit on capital projects was accompanied by high net returns. Indeed, labour productivity of a nation's workforce cannot be anything better than what its health sector can afford. Perhaps, what is thought-provoking finding here is that recurrent education expenditure and capital education expenditure were accompanied by low returns. Ordinarily, government recurrent expenditure on education, government 
capital expenditure on education and government capital expenditure on health impacted positively on economic development (Okafor, Jegbefumwen \& Ike, 2016). To resolve this impasse, it has become necessary to gain an insight into the nature of relationship between deficit financing and human capital investment. Trostel (1995) had observed that human capital investment is discouraged during deficit. And that because the tax rate is usually raised above its initial value to repay debt, the negative effect on human capital persists in the long-run. This finding confirms Laffer's (2004) finding that raising tax rates has negative economic effect by acting as disincentive to continue engagement in taxed activities.

Furthermore, there is the finding that economic growth and employment generation acted as incentives to tax-financing of budget deficit while private investment served as disincentive to it. Again, this finding has come much in expectation. Evidence abounds that public spending leads to growth-induced employment generation ( Okafor \& jegbefumwen, 2016). Economic growth leads to the empowerment of the citizenry, thereby enhancing their taxable capacity. Invariably, growth-induced employment generation works in double actions- enhancing the taxable capacity of the citizens on the one hand and enlarging the nation's tax base on the other. Equally so, there is nothing strange about the finding that private investment served as disincentive to tax-financing of budget in Nigeria. A logical explanation of this observed phenomenon is that the high lending rate, coupled with lack of basic infrastructures rendered private investment in Nigeria unprofitable, thereby discouraging their further participation in taxed productive activities. This finding is in concurrence with the finding reported by Paiko (2012), that there was inverse relationship between deficit financing and investment in the private sector of the Nigerian economy. This development was simply due to Laffer curve effect.

Still, there is this finding that there were long and short-run relationships among budget deficit, taxes, human capital investment and macroeconomic indicators with significant rate of adjustment of short-run disequilibrium. Surprising! This observation appears to be far detached from the realities on the floor of the Nigerian fiscal system. The long and short-run equilibrium relationships were not compatible with the frictional dislocation in the country's financial system manifesting in price instability, exchange rate volatility and macroeconomic instability. Along this line, Gbosi (2001) had stated that the cyclical changes in the Nigeria's economic activities led to periodic rise in country's unemployment and inflation rates as well as the external sector disequilibria. Perhaps, the only plausible explanation of the existence of these long and short-run relationships among the variables is that fiscal policy as a major stabilization weapon involving measures to regulate and control the volume, cost and availability of money was effective for achieving specified macroeconomic objectives (Gbosi, 1998).

\subsection{Conclusions}

The generalization drawn from this study is that tax-financing of budget deficits was effective in developing economies, within the limits of Laffer curve effect. Perhaps, what is required to formulate a dynamic tax-financing policy, in the face of operation of Laffer curve effect, is the preferred choice of growth-maximizing tax rate over revenue-maximizing tax rate. Certainly, this is the value which this study has added to the theory and policy of deficit financing. However, the generalizabilty of the evidences from this study could be limited by slight variation in fiscal policies and practices among developing economies. Notwithstanding, this study has added to economic literature a rich flavour of 'Laffer pessimism'. The real worth of this paper can be best appreciated with the implementation of the following recommendations: (1) The positive impact of custom and exercise duties, petroleum profit tax and value-added tax on budget deficit financing creates the need for governments to enlarge their tax bases so as to ensure inclusiveness, rather than raise existing tax rates or introduce new taxes (2) With low returns to company income tax, it has become necessary for LDCs to consider it a viable option to introduce tax holidays, tax exemptions and subsidy removal to attract new manufacturing firms and industries (3) High returns to tax-financing of capital health expenditures demand that LDCs extend the coverage of health insurance scheme to render health more accessible to the larger segment of their population (4) Low returns to tax-financing of recurrent education expenditure and capital education expenditure have placed a high premium on the urgent need of governments in LDCs to strive toward privatizing education at tertiary level in order to free resources for the provision of qualitative education at primary and secondary levels, and to provide jobs to the teeming population of school products.

\section{Acknowledgements}

We thank God, Father of Our Lord Jesus Christ for His abundant mercies and divine assistance. We are indebted to Mrs I.J. Okafor, wife of the principal researcher for her untiring efforts and commitment to this project.

\section{References}

Ariyo, A., \& Raheem, M. I. (1991). Effect of fiscal deficit on some macroeconomic aggregates in Nigeria, African Economic Research Consortium (AERC), Nairobi, Kenya.

Audu, I. (2004). The impact of external debt on economic growth and public investment: The case of Nigeria. African Institute for Economic Development and Planning (IDEP), Dakar, Senegal. http://www.unidep.org 
Edame, G. E., \& Okoi, O. B. (2015). Fiscal deficits and economic growth in Nigeria: A chow test approach. International Journal of Economics and Financial Issues, 5(3), 748-752.

Gaber, S. (2010). Economic implications from deficit finance. BERG Working Paper No. 69, 1-13.

Gbosi, A. N. (1998). Banks, financial crisis and the Nigerian economy today. Owerri: Corporate Impression Publishers.

Gbosi, A. N. (2001). Contemporary macroeconomic problems and stabilization policies in Nigeria. Port Harcourt :Antovic Ventures.

Jadhav, A., \& Neelankavil, J. (2011). Deficit financing- causes, consequences and potential cures. Journal of Applied Business and Economics, 12(6), 83-99.

Keho, Y. (2013). The structure of taxes and economic growth in Cote d'Ivoire : An econometric investigation. Journal of Research in Economics and International Finance, 2(3), 39-48.

Laffer, A. B. (2004). The laffer curve: Past, present and future. Executive Summary Backgrounder, No. 1765, 1-16. www.heritage.org/research/reports/2004/06/

Mitchell, D. J. (2010). The laffer curve shows that tax increases are a very bad idea - even if they generate more tax revenue. www.forbes.com/sites/danielmitchell/2012/04/15/

Ndedzu, D., Macheka, A., Ithiel, M. M., \& Zivengwa, T. (2013). Revenue productivity of Zimbabwe's tax system. Asian Journal of Social Sciences \& Humanities, 2(4), 144-156.

Nwaeke, G. C., \& Korgbeelo, C. (2016). Budget deficit financing and the Nigerian economy. European Journal of Business and Management, 8(22), 206-214.

Ogunmuyiwa, M. S. (2011). Does fiscal deficit determine the size of external debt in Nigeria? Journal of Economics and International Finance, 3(10), 580-585.

Ojo, A. S. (2014). Deficit financing and economic growth in Nigeria: A preliminary investigation. British Journal of Economics, Management \& Trade, 4(11), 1624-1643. https://doi.org/10.9734/BJEMT/2014/10618

Okafor, S. O., \& Jegbefumwen, K. (2016). Public spending for growth-induced employment: The Nigerian experience. British Journal of Economics, Management, \& Trade, 12(1), 1-19. https://doi.org/10.9734/BJEMT/2016/22685

Okafor, S. O., Jegbefumwen, K., \& Ike, A. N. (2016). Human capital investment for inclusive and sustainable economic development: The Nigerian experience. British Journal of Economics, Finance and Management Sciences, 11(1), 107-121.

Omojimite, B. U., \& Iboma, G. E. (2012). Fiscal deficit and the productivity of the Nigeria tax system, 1970-2010. Journal of Sustainable Development, 5(4), 116-125. https://doi.org/10.5539/jsd.v5n4p116

Onwe, B. U. (2014). Implication of deficit financing on economic growth in Nigeria. European Journal of Accounting, Auditing and Finance Research, 2(10), 122-135.

Oriakhi, D. E., \& Osemwengie, P. K. (2013). Tax incentives and revenue productivity of the Nigerian tax system. International Journal of Development and Economic Sustainability, 1(1), 31-44.

Paiko, I. I. (2012). Deficit financing and its implication on private sector investment: The Nigerian experience. Arabian Journal of Business and Management, 1(10), 45-62. https://doi.org/10.12816/0002187

Samuel, S. E., \& Tyokoso, G. (2014). Taxation and revenue generation :An empirical investigation of selected states in Nigeria. Journal of Poverty, Investment and Development, 4,102-114.

Tasneem, H. (2016). Theory of deficit budgets for development. www.yourarticlelibrary.com/india-2/theory-of-deficit-budgets-for-development/46720/

Thapa, G. B. (2005). Deficit financing: Implications and management. Economic Review, 16-26.

Trostel, P. A. (1995). The effect of deficit finance on human capital. National Tax Journal, 48(4), 531-546.

Upender, M. (2008). Degree of tax buoyancy in India: An empirical study. International Journal of Applied Econometrics and Quantitative Studies, 5(59-70).

\section{Copyrights}

Copyright for this article is retained by the author(s), with first publication rights granted to the journal.

This is an open-access article distributed under the terms and conditions of the Creative Commons Attribution license which permits unrestricted use, distribution, and reproduction in any medium, provided the original work is properly cited. 